\title{
Model CSR dalam Penguatan Modal Sosial dan Peran Kelembagaan Masyarakat
}

\author{
Suwandi', Sukaris ${ }^{2 *}$, Abdurahman Faris ${ }^{3}$ \\ 123 Universitas Muhammadiyah Gresik \\ ${ }^{1}$ suwandi@umg.ac.id, ${ }^{2}$ sukaris21@umg.ac.id, 3 faris_bukhori@yahoo.co.id \\ ${ }^{*}$ Penulis korespondensi
}

\begin{abstract}
The issue of community independence is the central theme of national development which is the responsibility of all elements of the nation, including government, the private sector and any organization. Viewed from the government's point of view, this is clearly seen from the partisanship of empowerment policies and development through village funds that are very adequate to reach a developed and empowered village. The implementation or practice of corporate social responsibility has a direct influence on the role of community institutions and the role of community institutions directly influences the strengthening of community social capital. This community institution directly influences the improvement of community welfare and CSR programs must be able to increase community capacity for long-term activities (sustainable). The company must continue to encourage program recipients to have responsibility and ownership of the program implemented in order to strengthen social capital and the Company must implement a more concrete CSR program in increasing income economically because it is the main goal in the concept triple bottom CSR.
\end{abstract}

Keywords: empowerment, social capital, welfare, CSR model, community institutions

\begin{abstract}
Abstrak
Isu kemandirian masyarakat menjadi tema sentral pembangunan nasional yang menjadi tanggung jawab semua elemen bangsa baik pemerintah, swasta dan organisasi apapun. Dilihat dari sudut pandang pemerintah, ini jelas terlihat dari keberpihakan kebijakan pemberdayaan dan pengembangan melalui dana desa yang sangat memadai untuk menuju desa yang maju dan berdaya. Implementasi atau praktek corporate social responsibility berpengaruh secara langsung terhadap peran kelembagaan masyarakat dan peran kelembagaan masyarakat berpengaruh secara langsung terhadap penguatan modal sosial masyarakat hal ini kelembagaan masyarakat berpengaruh secara langsung terhadap peningkatan kesejahteraan masyarakat serta program CSR harus dapat meningkatkan kemampuan masyarakat untuk kegiatan yang berjangka panjang (berkelanjutan). Perusahaan harus terus mendorong masyarakat penerima program memiliki tanggungjawab dan rasa memiliki atas program yang diimplementasikan dalam rangka memperkuat modal sosialnya dan Perusahaan harus mengimplementasikan program CSR yang lebih konkret dalam peningkatan pendapatan secara ekonomi karena menjadi tujuan utama dalam konsep triple bottom CSR.
\end{abstract}

Kata Kunci: pemberdayaan, modal sosial, kesejahteraan, model CSR, kelembagaan masyarakat 


\section{PENDAHULUAN}

Pembangunan nasional yang menjadi tanggung jawab semua elemen bangsa baik pemerintah, swasta dan organisasi apapun. Dilihat dari sudut pandang pemerintah, ini jelas terlihat dari keberpihakan kebijakan pemberdayaan dan pengembangan melalui dana desa yang sangat memadai untuk menuju desa yang maju dan berdaya. Kebijakan ini juga bisa dimaknai sebagai perwujudan dari nawacita sembilan agenda prioritas pemerintah Jokowi-JK yakni nawa cita yang ketiga adalah melakukan pembangunan Indonesia daerah pinggiran dengan cara pengkuatan daerah perdesaan dan pesisir dalam mewujudkan Negara kesatuan republic Indonesia seutuhnya, serta nawa cita ketujuh yaitu mewujudkan kemandirian ekonomi dengan menggerakkan sektor-sektor strategis ekonomi domestik.

Keperpihakan dari pihak lain misalnya dapat dilihat dengan kontribusi-kontribusi perusahaan milik Negara (BUMN) maupun perusahaan swasta untuk terlibat dalam pengembangan masyarakat, pemberdayaan menuju sustainable development goals (SDG's). Perusahaan milik Negara adalah bagian dari aktivitas yang banyak melibatkan masyarakat dan lingkungan industry dan bentuk rasa tanggung jawab social mereka atas aktivitas usaha yang dilakukan ditengah-tengah masyarakat sebagai bentuk kepedulian perusahaan akan tanggung jawab sosial masyarakat dari lembaga yang memberikan model kegiatan social atau corporate social responsibility (CSR) masyarakat sekitar perusahaan.

Kegiatan sosial yang diberikan seperti CSR merupakan sebagai bentuk rasa pertanggungjawaban perusahaan kepada lingkungan masyarakat dan lingkungan sekitar industry dalam memberikan kepedulian, masyarakat sekitar industri dan lingkungan perusahaan merupakan pihak yang perlu mendapatkan perhatian dari perusahaan secara langsung maupun tidak langsung terkena dampak dari kegiatan industry perusahaan. Hal ini kemampuan ekonomi sekitar masyarakat dan di sekitar kawasan industry perusahaan yang berdampak pada perusahaan dan lingkungan. Melalui praktek program CSR diharapkan dapat meningkatkan pemberdayaan masyarakat baik yang bersifat ekonomi maupun non ekonomi, dan begitu juga keuntungan balik bagi perusahaan salah satunya meningkatnya reputasi perusahaan dimata masyarakat.

Peningkatan ekonomi seperti halnya meningkatnya jumlah pendapatan, meningkatnya kesejahteraan, meningkatnya jumlah-jumlah produk yang dihasilkan, menurunnya tingkat kemiskinan dan meningkatnya usaha-usaha ekonomi lain baik secara langsung maupun tidak langsung. Peningkatan secara non ekonomi dapat dilihat misalnya; menguatnya kapasitas masyarakat, menguatnya fungsi kelembagaan, menguatnya modal sosial masyarakat dan meningkatnya pembangunan-pembangunan desa dan masyarakat secara fisik.

Peran tanggungjawab social atau corporate social responsibility (CSR) terdapat 3 pilar utama pembangunan (triple tracks) sebagai berikut: (1) akan pengurangan jumlah pengangguran (pro-job) dan peningkatan angkatan kerja (2) pengurangan jumlah penduduk miskin (pro-poor) dan menaikan nilai pendapatan perkapita dan (3) peningkatan pertumbuhan ekonomi (pro-growth) dan kestabilan harga serta daya beli masyarakat.

Pemberdayaan secara umum memiliki makna penting yaitu meningkatkan kemampuan masyarakat dan memberikan ruang dalam pengambilan keputusan. Model permberdayaan 
yang berbasis top down atau juga disebut strategi uniformitas terkadang kurang efektif dan kurang sesuai yang dibutuhkan, sehingga alternative lain adalah melakukan upaya perencanaan Praktek corporate social responsibility berbasis kebutuhan (bottom up) tanpa mengesampingkan level kinerja dari perusahaan itu sendiri. Praktek program CSR akan dapat memperkuat modal sosial masyarakat jika praktek tersebut melibatkan warga masyarakat dalam tahapan imlementasi program, program CSR akan memberikan peningkatan atau kegunaan bagi kehidupan masyarakat, program CSR mampu meningkatkan kapasitas masyarakat dan dapat memperkuat kelembagaan-kelembagaan masyarakat. Asumsi tersebut akan memungkinkan masyarakat dapat beriteraksi semakin menguatnya modal sosial masyarakat.

Output atau keberhasilan dari Praktek program model CSR salah satunya adalah semakin menguatnya modal sosial masyarakat, karena modal social masyarakat maka akan terjalin masyarakat yang harmonis, masyarakat yang berinterksi dengan lingkungan perusahaan dan memiliki hubungan yang harmonis akan terjalin kerjsama yang salin melengkapi dalam masing-asing kepentingan. Masyarakat dan lingkungan perusahaan akan terpola dan terstruktur dalam melakukan kerjasama dalam kegiatan secara bersama-sama. Tanggungjawab perusahaan akan sesuai dengan kebutuhan masyarakat dengan pola kelembagaan yang memberikan penghubungan dari berbagai kepentingan masyarakat (Narsa dan Irwanto, 2014). Terciptanya kondisi tersebut memungkinkan masyarakat akan dapat lebih memiliki peluang kesejahteraan baik dilevel individu, keluarga maupun level masyarakat. Asumsi bahwa modal sosial akan dapat berperan serta dalam meningkatkan kesejahteraan ekonomi masyarakat lingkungan perusahaan. jika modal sosial terdiri dari tanggung jawab, partisipasi, Intensitas interaksi kerjasama, kepercayaan dan kesamaan idea atau gagasan

Berkembangnya kompleksitas dinamika perubahan masyarakat desa yang terjadi tersebut sebagai dampak kebebasan untuk mendapatkan informasi dalam meningkat taraf kesejahteraannya, sehingga setiap warga negara dapat berperan untuk mewujudkan peningkatan kualitas hidup masyarakat, serta kemajuan bangsa dan negaranya. Freedman dalam (Setyaningrum, 2011) keberadaan model CSR akan melekat secara inherent dengan tatakelola manajemen perusahaan, sehingga bentuk kegiatan dalam model CSR dapat dikontrol oleh manajemen perusahaan. Dilingkungan masyarakat sekitar perusahaan adalah pihak yang terpenting untuk memperoleh apresiasi atau perhatian. Apresiasi atau perhatian itu sendiri dapat memberikan perubahan kesejahteraan hidup melalui kegiatan pemberdayaan ekonomi masyarakat yang dilakukan oleh manajemen perusahaan melalui kegiatan social atau CSR, sehingga kesejahteraan tersebut mampu meningkatkan kualitas pendidikan, meningkatkan kualitas kesehatan dan juga mampu meningkatkan penghasilan masyarakat.

Salah satu perusahaan yang telah lama mengpraktekkan program CSR adalah PT PJB UP Gresik sebagai salah satu holding dari PT PLN yang bergerak dalam produksi energi listrik. Perkembangan Praktek CSR PT PJB UP Gresik dalam satu terakhir dalam memberdayakan masyarakat tampak dalam mengembangkan masyarakat pada programprogram yang bersifat sustainable diantaranya adalah pemberdayaan bank sampah di desa Kramattinggil, Pokdatan di desa Sidorukun, kampong organik, penguatan komunikasi antar warga melalui forum komunikasi polisi dan masyarakat dan banyak lagi yang terangkum 
dalam 4 bidang aktuator program yaitu; pendidikan, kesehatan sosial ekonomi budaya dan keagamaan serta lingkungan (Moch dan Sukaris, 2018)

Peran besar Praktek CSR sudah seharusnya dapat menghadirkan dampak keluarankeluaran positif diantaranya adalah semakin mendorong peran aktif kelembagaan dan memperkuat modal sosial masyarakat, sebagai modal masyarakat dalam melaksanakan program pembangunan serta secara individu dan komunitas dapat meningkatkan taraf kesejahteraan. Untuk itu penelitian ini menjadi kontribusi menarik dalam memberikan keyakinan stakeholder peran penting Praktek CSR. Keberlangsungan bisnis dapat berjalan lama dan dalam jangka panjang, kegiatan usaha harus memberi harapan akan kebutuhan masyarakat. Keberhasilan masyarakat di dalam memecahkan masalah ekonomi akan dapat dilihat dari kemiskinan dan kelaparan. Hubungan dunia bisnis dan masyarakat akan memberikan nilai kemanfaatan akan tetapi dalam masalah sosial menghasilkan kondisi lingkungan ekonomi serta memberi hal yang baik bagi pengelola bisnis yang menghasilkan keuntungan yang maksimal (Simorangkir OP, 2003)

Holme and Watts dalam (Hadi, 2011) mendefinisikan Corporate Social Responsibility is a form of the company's continued commitment to business in order to behave ethically and contribute to economic development to improve the quality of life of the workforce and their families, as well as the environmental community of the company and society in general. Istilah CSR mulai digunakan sejak tahun 1970 an dan semakin popular setelah kehadiran buku cannibals with FORKS: The triple Botton Line in 21st Century Business (1998) karya John Elkington (Hadi, 2011) mengembangkan 3 komponen penting suistabinable development, yakni economic growth, environment protection dan social equity yang ditugaskan the world Commission On Environmental and development (WCED), Elkington mengemas CSR dalam 3 fokus yakni 3P, singkatan dari profit, planet dan people. Perusahaan yang baik tidak hanya mengejar keuntungan ekonomi semata (profit) melainkan harus memiliki kepekaan dan kepedulian akan lingkungan (planet) disekitar perusahaan dan kesejahteraan masyarakat lingkungan perusahaan (people) dan keterlibatan masyarakat lingkungan sekitar perusahaan sebagai bentuk kontribusi perusahan pada masyarakat.

Secara umum CSR merupakan peningkatan kualitas kehidupan mempunyai adanya kemampuan manusia sebagai individu anggota masyarakat untuk menanggapi keadaan sosial yang ada dan dapat dinikmati, memanfaatkan serta memelihara lingkungan hidup. Atau dengan kata lain merupakan cara perusahaan mengatur proses usaha untuk memproduksi dampak positif pada komonitas atau citra yang baik. Ghana dalam (Hadi, 2011) memberikan batasan mengenai "Corporate Social Responsibility merupakan memberikan kapasitas dalam membangun corporate building menuju terjaminnya going concern perusahaan, didalamnya termasuk upaya peka (respect) terhadap adopsi sistemik berbagi budaya (kearifan lokal) ke dalam strategi bisnis perusahaan, termasuk ketrampilan karyawan, masyarakat dan pemerintah.

Model tanggung jawab social atau CSR belum banyak dilakukan. Teori korporasi klasik, model dan konsep tangungjawab social atau CSR sangat beragam. Model dan konsep yang digunakan berkaitan dengan CSR akan berpijak pada dua perkembangan seperti: pertama, dalam realitasnya pelaksana dari pemerintah tidak secara keseluruhan menjalankan kesejahteraan yang telah diprogramkan. Kedua, kegagalan pasar yang tidak 
efesien sehingga akan berdampak pada masyarakat sekitar perusahaan. Hal itu terjadi apabila, salah satu tindakan agen pasar, ternyata menimbulkan dampak bagi kesejahteraan atau kondisi pihak lainnya. Dampak dalam kegagalan akan mempengaruhui hasil pelaksanan kegiatan perusahaan dan masyarakat sekitar perusahaan.

Tiga pilar akan memberikan dampak pada pertumbuhan tanggungjwab social perusahaan atau CSR yang mampu mendorong laju pembangunan ekonomi berkelanjutan di berbagai sector dengan bentuk model dan konsep CSR yang efektif untuk mencapai tujuan perusahaan yang sudah diprogramkan, Sumber Daya Manusia memiliki peran dalam menjalankan program kegiatan tanggungjawab sosial dan CSR akan dapat maksimal akan tergantung pada lembaga yang menjalankannya sehinga peran masyarakat, pembuat UU, pekerja, pelaku bisnis, sebagai obyek dalam pelaksanaan CSR dan tiga pilar agar dapat berjalan maksimal membutuhkan komitmen dan pelaksanaan kegiatan yang menyeluruh pada lapisan masyarakat, semua perusahaan berkomitmen dan masyakarat melalukan pelaksanan sesuai dengan program yang diprogramkan perusahaan.

Model dan konsep CSR akan memaksa korporasi sebagai agen ekonomi yang mengikuti prosedur hukum dan peraturan yang telah disepakati, kepedulian terhadap masalah sosial di lingkungan perusahaan, kepedulian terhadap perlindungan lingkungan hidup akan masyarakat sekitar, kebersihan dan kesehatan kerja masyarakat sekitar perusahaan, good corporate citizenship akan berperan pada hasil tanggungjawab social lingkungan sehingga perusahaan harus meminimalkan eksternalitas yang negative pada masyarakat.

Penelitian-penelitian terdahulu terkait corporate social responsibility, khususnya penelitian di Indonesia telah banyak dilakukan oleh peneliti peneliti bidang sosial, manajemen dan keuangan (Arendt dan Brettel, 2010; Carroll dan Shabana, 2010; Giannarakis, dkk., 2016; Lins, Servaes, dan Tamayo, 2017; Peloza dan Falkenberg, 2012; Permanasari, 2010; Semuel dan Wijaya, 2007; Septiana, 2012; Susanti dan Mildawati, 2014), penelitian-penelitian ini lebih banyak membahas corporate social responsibility yang dikaitkan dengan nilai perusahaan, kinerja pemasaran dan profitafilitas perusahaan. Demikian juga penelitian terkait dengan peran CSR dan peningkatan peran kelembagaan juga pernah dilakukan diantaranya (Ana Jacinto, 2009; Ansari, Munir, dan Gregg, 2012; Hoi, Wu, dan Zhang, 2018; Ismail, Alias, dan Rasdi, 2015; Jamali dan Karam, 2018; Wang, dkk., 2016; Young dan Thyil, 2014). Sedangkan penelitian yang menghubugkan antara CSR dan modal sosial masyarakat telah dilakukan oleh (Chintia dan Nasdian, 2017; Hasan Asy'ari, 2009; Mentari, 2013; Nugraha, dkk., 2015; Rosyida dan Nasdian, 2011; Supono, 2011; Suryani dan Hendra, 2018)

Begitu juga penelitian CSR yang berhubungan dengan kesejahteraan masyarakat telah dilakukan dalam 5 tahun terakhir yakni oleh (Ariefianto, 2015; Astiti dan Saitri, 2016; Maroni, Kusuma, dan Alaydrus, 2017; Nirmaya, Muflikhati, dan Simanjuntak, 2014; Putu Wenny Saitri, 2016; Rahmadani, Raharjo, dan Resnawaty, 2019; Sa'Diyah dan Budiani, 2015; Sofyanty, Hamid, dan Dewantara, 2017). Namun demikian penelitian-penelitian tersebut belum bersifat integrative sehingga perlu sebuah variabel yang dapat memperjelas hubungan antara program CSR dengan modal sosial dan kesejahteraan mayarakat. Berdasarkan hal tersebut penelitian ini bertujuan mengetahui pengaruh program CSR terhadap peningkatan kesejahteraan dan penguatan modal sosial melalui peran kelembagaan masyarakat. 


\section{METODE}

\section{Gambar 1. Model Penelitian}

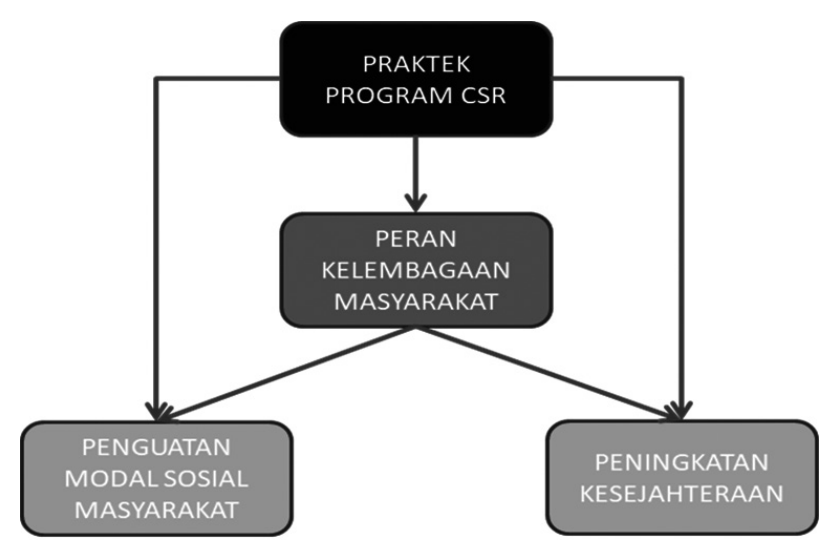

Dalam menjawab tujuan penelitian, menguji hubungan antar variabel dan menilai model yang disusun, teknik analisis yang digunakan adalah teknis analisis jalur dengan menggunakan program software SPSS. Namun sebelumnya dilakukan uji validaitas dan reliabilitas instrument untuk diketahui validitas dan konsistensi instrument yang digunakan. Persamaan model analisis jalur disajikan sebagai berikut: 1) Persamaan satu; $Z=a+b_{1} X+e .2$ ) Persamaan dua; $Y_{1}=a+b_{2} X+b_{2} Z+b_{3} X * Z_{1+}$ e. 3) Persamaan tiga; $Y_{2}=a+b_{4} X+b_{5} Z+b_{6} X * Z_{2}+e$.

\section{HASIL DAN PEMBAHASAN}

Berdasarkan hasil uji hipotesis yang disajikan pembahasan penelitian. Ada tiga hipotesis yang diuji pada penelitian ini dan terbukti ketiga hipotesis tersebut menunjukkan pengaruh yang signifikan.

Tabel 1. Koefisien regresi persamaan satu

Coefficients $^{\mathrm{a}}$

\begin{tabular}{|c|c|c|c|c|c|c|}
\hline & \multirow{2}{*}{ Model } & \multicolumn{2}{|c|}{$\begin{array}{l}\text { Unstandardized } \\
\text { Coefficients }\end{array}$} & \multirow{2}{*}{$\begin{array}{c}\text { Standardized } \\
\text { Coefficients } \\
\text { Beta }\end{array}$} & \multirow{2}{*}{$\mathbf{t}$} & \multirow{2}{*}{ Sig. } \\
\hline & & B & $\begin{array}{l}\text { Std. } \\
\text { Error }\end{array}$ & & & \\
\hline \multirow[t]{2}{*}{1} & (Constant) & 6.864 & 2.3 & & 2.984 & .004 \\
\hline & Implementasi Program CSR & .787 & .134 & .509 & 5.861 & .000 \\
\hline
\end{tabular}

a. Dependent Variable: Peran Kelembagaan Masy

Persamaan satu; $\mathrm{Z}_{1}=\mathrm{a}+\mathrm{b}_{1} \mathrm{X}+\mathrm{e}$, berdasarkan hasil analisis sebagaimana hasil analisis data dapat diperoleh persamaan model sebagai berikut; $Y=6.864+0.787 \mathrm{X}+0.134$

Berdasarkan persamaan regresi yang telah dibuat maka dapat dibuat arah jalur dari variabel bebas terhadap variable terikatnya yaitu apabila X (implementasi program CSR) meningkat satu point maka akan menaikkan Z (peran kelembagaan masyarakat) sebesar 0.787 poin, begitu juga perubahan dalam peran kelembagaan masyarakat dapat dijelaskan 
oleh implementasi program Corporate Social Responsibility sebesar 26\% dan kedua variable ini memiliki keeratan hubungan sebesar 50.9\%.

Tabel 2. Koefisien regresi persamaan dua

Coefficients $^{\mathrm{a}}$

\begin{tabular}{|c|c|c|c|c|c|c|}
\hline & \multirow{2}{*}{ Model } & \multicolumn{2}{|c|}{$\begin{array}{l}\text { Unstandardized } \\
\text { Coefficients }\end{array}$} & \multirow{2}{*}{$\begin{array}{c}\text { Standardized } \\
\text { Coefficients } \\
\text { Beta }\end{array}$} & \multirow{2}{*}{$\mathbf{t}$} & \multirow{2}{*}{ Sig. } \\
\hline & & B & $\begin{array}{l}\text { Std. } \\
\text { Error }\end{array}$ & & & \\
\hline \multirow[t]{3}{*}{1} & (Constant) & 9.304 & 2.745 & & 3.389 & .001 \\
\hline & $\begin{array}{c}\text { Implementasi Program } \\
\text { CSR }\end{array}$ & .438 & .178 & .246 & 2.456 & .016 \\
\hline & Peran Kelembagaan Masy & .417 & .115 & .362 & 3.615 & .000 \\
\hline
\end{tabular}

a. Dependent Variable: Penguatan Modal Sosial Masyarakat

Persamaan dua; $Y_{1}=a+b_{2} X+b_{2} Z+b_{3} X * Z_{1+} e$, berdasarkan hasil analisis sebagaimana hasil analisis data dapat diperoleh persamaan model sebagai berikut; $Y_{1}=9.304+0.438 X+0.41$ $7 Z+0.787 * 0.417 \mathrm{XZ}$, dalam persamaan regresi yang telah dibuat maka dapat dibuat arah jalur dari variabel bebas terhadap variable terikatnya yaitu apabila X (implementasi program CSR) meningkat satu poin maka akan menaikkan $Y_{1}$ (penguatan modal sosial masyarakat) sebesar 0.438 poin dengan asumsi tanpa melihat adanya peningkatan peran kelembagaan masyarakat, begitu juga perubahan satu poin dalam peran kelembagaan masyarakat maka akan dapat meningkatkan modal sosial masyarakat sebesar 0.417 poin tanpa melihat implementasi CSR terprogram. Arah jalur tidak langsung antara Implementasi program Corporate Social Responsibility melalui peran kelembagaan sebesar 0.328179. Implementasi program Corporate Social Responsibility dan peran kelembagaan memiliki keeratan hubungan dalam menperkuat modal sosial masyarakat sebesar 53.1\% dan kedua variable ini mampu menjelaskan perubahan penguatan modal sosial masyarakat dalam hal program CSR perusahaan sebesar $28.2 \%$ hal ini didukung pengaruh kedua variable bebas implementasi program CSR dan peran kelembagaan masyarakat terhadap kuat tidaknya modal masyarakat sebesar 19.004 .

Tabel 3. Koefisien regresi persamaan tiga

Coefficients

\begin{tabular}{|c|c|c|c|c|c|c|}
\hline & \multirow[t]{2}{*}{ Model } & \multicolumn{2}{|c|}{$\begin{array}{l}\text { Unstandardized } \\
\text { Coefficients }\end{array}$} & \multirow{2}{*}{$\begin{array}{c}\text { Standardized } \\
\text { Coefficients } \\
\text { Beta }\end{array}$} & \multirow[t]{2}{*}{$\mathbf{t}$} & \multirow[t]{2}{*}{ Sig. } \\
\hline & & B & Std. Error & & & \\
\hline \multirow[t]{3}{*}{1} & (Constant) & 3.085 & 1.53 & & 2.015 & 0.047 \\
\hline & $\begin{array}{c}\text { Implementasi Program } \\
\text { CSR }\end{array}$ & 0.316 & 0.099 & 0.324 & 3.179 & 0.002 \\
\hline & Peran Kelembagaan Masy & 0.161 & 0.064 & 0.255 & 2.501 & 0.014 \\
\hline
\end{tabular}

a. Dependent Variable: Peningkatan Kesejahteraan Masyarakat 
Persamaan tiga; $\mathrm{Y}_{2}=\mathrm{a}+\mathrm{b}_{4} \mathrm{X}+\mathrm{b}_{5} \mathrm{Z}+\mathrm{b}_{6} \mathrm{X} * \mathrm{Z}_{1}+\mathrm{e}$, berdasarkan hasil analisis sebagaimana hasil olah data dapat diperoleh persamaan model sebagai berikut; $Y_{2}=3.085+0.316 X+0.161$ $\mathrm{Z}_{1}+0.787 * 0.161 \mathrm{XZ}$

Berdasarkan persamaan regresi yang telah dibuat maka dapat dibuat arah jalur dari variabel bebas terhadap variable terikatnya yaitu apabila X (implementasi program CSR) meningkat satu poin maka akan menaikkan $\mathrm{Y}_{2}$ (Kesejateraan masyarakat) sebesar 0.316 poin dengan asumsi tanpa melihat adanya peran kelembagaan masyarakat, begitu juga perubahan satu poin dalam peran kelembagaan masyarakat maka akan dapat meningkatkan kesejahteraan masyarakat sebesar 0.161 poin tanpa melihat implementasi program CSR. Arah jalur tidak langsung antara Implementasi program Corporate Social Responsibility terhadap peningkatan kesejahteran masyarakat melalui peran kelembagaan sebesar 0.126707. Implementasi program Corporate Social Responsibility dan peran kelembagaan masyarakat memiliki keeratan hubungan dalam peningkatan kesejahteraan masyarakat sebesar $50.4 \%$ dan kedua variable ini mampu menjelaskan perubahan kesejahteraan dalam hal program CSR perusahaan sebesar $25.4 \%$ hal ini didukung pengaruh kedua variable bebas implementasi program CSR dan peran kelembagaan masyarakat terhadap peningkatan kesejahteraan masyarakat.

Berdasarkan hasil penelitian pada Tabel 1, Tabel 2 dan Tabel 3, persamaan analisis regresi menunjukkan pengaruh dimasing-masing variable yang bervariatif. Variable implementasi program social responsibility signifikan berpengaruh terhadap penguatan modal sosial masyarakat, Secara umum CSR merupakan peningkatan kualitas kehidupan mempunyai adanya kemampuan manusia sebagai individu anggota masyarakat untuk menanggapi keadaan sosial yang ada dan dapat dinikmati, memanfaatkan serta memelihara lingkungan hidup.

Hasil penelitian menunjukkan bahwa program implementasi CSR perusahaan yang dilakukan dengan melibatkan partisipasi masyarakat, program-program yang bermanfaat, program yang dapat mengembangkan pengetahuan dan program yang dapat meningkatkan kerjasama antar warga masyarakat akan dapat meningkatkan peran kelembagaan masyarakat. Maka dengan kata lain jika implementasi program CSR yang dapat menghadirkan pelibatan, partisipasi, kebermanfaatan maka akan meningkatkan peran kelembagaan yang ada dimasyarakat diantaranya kelembagaan ekonomi(usaha) akan mampu menjadi media komunikasi antar warga dan juga sebagai sarana saling memberdayakan. Hasil penelitian ini mendukung pendapat (Wibisono, 2007) Pembangunan Berkelanjutan dapat diukur berdasarkan tiga kriteria (KLH, 1990).

Tidak ada pemborosan penggunaan SDA, Tidak ada polusi dan dampak lingkungan dan kegiatannya harus dapat meningkatkan useable resources Enviromental Economic Society Well-being piramida keberlanjutan Tata Penyelenggaraan Pemerintahan yang Baik (Good Governance), Keberlanjutan Kelembagaan Deklarasi Johannesburg untuk Pembangunan Berkelanjutan, Semakin tinggi tingkat implementasi program CSR di bidang lingkungan maka semakin tinggi efektivitas program CSR. Semakin tinggi efektivitas program CSR di bidang lingkungan maka semakin menuju sustainable development. Kinerja atribut program: tingkat kepentingan, tingkat kinerja atribut, tingkat kepuasan keberlanjutan kelembagaan, tingkat keseimbangan pelayanan-peran, serta, tingkat demokrasi, transparansi, akuntabilitas, jejaring kelembagaan. 
Variable implementasi program social responsibility signifikan berpengaruh terhadap penguatan modal sosial masyarakat, Secara umum CSR merupakan peningkatan kualitas kehidupan mempunyai adanya kemampuan manusia sebagai individu anggota masyarakat untuk menanggapi keadaan sosial yang ada dan dapat dinikmati, memanfaatkan serta memelihara lingkungan hidup.

Hasil penelitian menunjukkan bahwa program CSR perusahaan yang dilakukan dengan melibatkan partisipasi masyarakat, program-program yang bermanfaat, program yang dapat mengembangkan pengetahuan dan program yang dapat meningkatkan kerjasama antar warga masyarakat akan dapat memperkuat modal sosial masyarakat. Maka dengan kata lain jika implementasi program CSR yang dapat menghadirkan pelibatan, partisipasi, kebermanfaatan maka akan meningkatkan modal sosial yang ada dimasyarakat diantaranya kepercayaan (trust), norma-norma (norms), dan jaringan-jaringan (networks).

Hasil penelitian ini mendukung pendapat (Aprianthiny, 2015) bahwa CSR dan modal sosial terdapat hubungan dua arah yang bersifat kausalitas dan saling mempengaruhi serta hasil penelitian menyatakan Implementasi CSR pada PT. Tirta Mumbul Jaya Abadi dikategorikan sebagai modal sosial karena salah satu keberhasilan perusahaan adalah keberlanjutan usaha. Keberlanjutan usaha itu dapat dilihat dari organisasi pihak internal dan pihak eksternal. CSR adalah salah satu faktor keberlanjutan usaha dengan jalan meningkatkan kepercayaan terhadap pihak eksternal, khususnya kepada lingkungan masyarakat karena dengan diterapkannya CSR perusahaan dituntut untuk lebih bertanggung jawab atas lingkungan dan masyarakat sekitar perusahaan.

Implementasi program social responsibility signifikan berpengaruh terhadap peningkatan kesejahteraan masyarakat, Secara umum CSR merupakan peningkatan kualitas kehidupan mempunyai adanya kemampuan manusia sebagai individu anggota masyarakat untuk menanggapi keadaan sosial yang ada dan dapat dinikmati, memanfaatkan serta memelihara lingkungan hidup.

Hasil penelitian menunjukkan bahwa program CSR perusahaan yang dilakukan dengan melibatkan partisipasi masyarakat, program-program yang bermanfaat, program yang dapat mengembangkan pengetahuan dan program yang dapat meningkatkan kerjasama antar warga masyarakat akan dapat meningkatkan kesejahteraan masyarakat. Hasil penelitian ini mendukung penelitian (Mapisangka, 2009) dalam penelitian Implementasi CSR terhadap Kesejahteraan Hidup Masyarakat bahwa Variabel-variabel seperti corporate so-cial responsibility goal, corporate social issue dan corporate relation program secara signifikan memiliki pengaruh positif terhadap peningkatan kesejahteraan hidup masyarakat dan diantara variabel-variabel tersebut, variabel corporate relation program memiliki pengaruh yang paling besar dalam mempengaruhi peningkatan kesejahteraan hidup masyarakat di lingkungan kawasan industri Batamindo, Batam.

Kelembagaan Masyarakat akan memiliki peran penting jika kelembagaan yang dibentuk oleh masyarakat memiliki manfaat bagi masyarakat dan juga mereka yang ada didalam kelembagaan itu, dalam kaitan dengan corporate social responsibility kelembagaan yang paling mungkin adalah kelembagaan-kelembagaan yang mewadahi dalam bidang ekonomi 
dan juga sosial kemasyarakatan, missal kelompok usaha bersama, forum-forum keamanan dalam masyarakat, kelompok-kelompok budaya dan sebagainya. Bahwa kelembagaan ini memiliki peran penting terhadap penguatan modal masyarakat, karena dengan kelembagaan ini masyarakat dapat meningkatkan kapasitas, terlibat aktif dalam partisipasi pembangunan desa, terlibat aktif dalam pengambilan keputusan, sebagai sarana berkomunikasi dengan masyarakat, serta sebagai sarana pemberdayaan warga.

Hasil penelitian ini menunjukkan bahwa peran kelembagaan masyarakat berpengaruh langsung terhadap penguatan modal sosial masyarakat, sebagaimana pendapat (Syahra, 2003) jika CSR berhasil diaplikasikan dengan baik, maka kontribusi terpenting pengembangan modal sosial adalah terciptanya kelompok masyarakat yang semakin mandiri, yang mampu berpartisipasi secara lebih berarti dalam mewujudkan good governance atau tata pemerintahan yang baik. Sehingga dapat dikatakan bahwa peran kelembagaan menjadi salah satu syarat penting bagi suksesnya implementasi program corporate social responsibility perusahaan.

Gagasan awal pelaksanaan CSR adalah sebuah konsep dimana organisasi memutuskan untuk berkontribusi dalam kesejahteraan masyarakat dan lingkungan. Jadi CSR sebagai dorongan dari perusahaan untuk memberikan kontribusi positif di bidang sosial, ekonomi, dan lingkungan termasuk didalamnya untuk terlibat dalam mensejahterakan. Kesejahteraan masyarakat dapat diukur dengan meningkatnya taraf kehidupan manusia untuk lebih baik, (Astiti dan Saitri, 2016; Sa'Diyah dan Budiani, 2015) menyatakan ada hubungan Program CSR dengan Kesejahteraan Masyarakat.. Salah satu indiaktor penting peran kelembagaan dalam berkontribusi untuk meningkatkan kesejahteraan masyarakat adalah jika kelembagaan yang ada di masyarakat dapat meningkatkan kapasitas warga, terlibat aktif dalam partisipasi pembangunan desa, terlibat aktif dalam pengambilan keputusan, sebagai sarana berkomunikasi dengan masyarakat, serta sebagai sarana pemberdayaan warga maka kesejahteraan akan bisa terangkat, hasil ini sejalan dengan penelitian ini dimana kelembagaan masyarakat memiliki pengaruh langsung terhadap peningkatan kesejahteran masyarakat.

Implementasi program model CSR merupakan bentuk dari kualitas kehidupan lingkungan perusahaan yang mempunyai kemampuan manusia sebagai individu anggota masyarakat yang berperan untuk menanggapi keadaan sosial yang ada dan dapat dinikmati dan dimanfaatkan, memanfaatkan serta memelihara lingkungan hidup. Hasil penelitian menunjukkan bahwa Implementasi program CSR perusahaan yang dilakukan dengan melibatkan partisipasi masyarakat, program-program yang bermanfaat, program yang dapat mengembangkan pengetahuan dan program yang dapat meningkatkan kerjasama antar warga masyarakat akan dapat membentuk atau mempengaruhi penguatan modal sosial masyarakat.

Penguatan modal sosial masyarakat ini terdiri dari menjadikan anda lebih bertanggungjawab atas sebuah kegiatan, berkeiinginan untuk berpartisipasi untuk mensukseskan program kegiatan tersebut, berinteraksi dengan warga yang lain, semangat bekerjasama dengan warga yang lain, meningkatkan saling percaya dengan yang lain, dapat menyamakan ide-ide dengan warga yang lain. Penguatan modal sosial masyarakat ini juga dapat melalui peran kelembagaan yang ada dimasyarakat. Implementasi program CSR selain memperkuat modal sosial masyarakat juga dapat meningkatkan taraf kesejahteraan masyarakat seperti mampu meningkatkan kualitas pendidikan, mampu meningkatkan kualitas kesehatan, tingkat pendapatan semakin 
meningkat. Hasil Penelitian ini mendukung (Cahyono, 2014) bahwa Tingkat kesejahteraan dan pengurangan kemiskinan dapat dilakukan tidak hanya melalui pemberdayaan ekonomi, namun juga melalui penguatan modal sosial, dan community development. Penguatan sosial dapat dilakukan dengan mengembangkan skema-skema penguatan modal sosial, seperti peningkatan fungsi BPD, LKMD, Gapoktan, PKK, BUMDes, dan Koperasi.

Pengaruh Modal Sosial Terhadap Partisipasi masyarakat Dalam Program Corporate Social Responsibility (CSR) dan dampaknya Bagi Kemampuan Ekonomi Masyarakat, dari studi dokumentasi menyimpulkan bahwa CSR merupakan hal yang tak terpisahkan dalam usaha penciptaan kesejahteraan masyarakat, begitu pula dengan partisipasi. Tingkat partisipasi masyarakat dalam CSR memiliki keterkaitan dengan kemampuan ekonomi masyarakat. Secara umum, fungsi kelembagaan yang ada didalam masyarakat sebagai wadah pemberdayaan mendapat penilaian yang besar oleh masyarakat. Pemberdayaan sendiri merupakan serangkaian kegiatan untuk memperkuat kekuasaan kelompok lemah dalam masyarakat, termasuk individu-individu yang mengalami masalah ekonomi.

Pemberdayaan ekonomi masyarakat local dilingkungan perusahaan berarti memampukan masyarakat sekitar untuk dapat mandiri secara ekonomi atau setidak-tidaknya memberikan motivasi agar terjadi perkembangan ekonomi di daerah sekitar perusahaan. Dengan adanya CSR diharapkan dapat memberikan pengaruh positif terhadap kesejahteraan masyarakat dan pengembangan perekonomian masyarakat sekitar. Pemberdayaan masyarakat dapat terwujud dengan adanya pelibatan masyarakat secara utuh dalam pelaksanaannya. Dengan pelibatan secara utuh tersebut, dapat memperkuat modal sosial yang ada di dalam masyarakat dan hal ini akan berdampak positif bagi kesejahteraan dan keberlanjutan nilai perusahaan.

\section{SIMPULAN}

Simpulan atas hasil penelitian ini adalah implementasi atau praktek corporate social responsibility berpengaruh secara langsung terhadap peran kelembagaan masyarakat, mmplementasi atau praktek corporate social responsibility berpengaruh secara langsung terhadap penguatan modal sosial masyarakat, implementasi atau praktek corporate social responsibility berpengaruh secara langsung terhadap peningkatan kesejahteraan masyarakat, bahwa peran kelembagaan masyarakat berpengaruh secara langsung terhadap penguatan modal sosial masyarakat, bahwa peran kelembagaan masyarakat berpengaruh secara langsung terhadap peningkatan kesejahteraan masyarakat, dan hasil yang terakhir implementasi atau praktek corporate social responsibility berpengaruh terhadap penguatan modal sosial masyarakat dan peningkatan kesejahteraan masyarakat melalui peran kelembagaan masyarakat.

Hasil penelitian dapat menjadi kesempatan untuk praktik managerial dan agenda penelitian yang akan datang. Terdapat beberapa hal yang perlu mendapat perhatian dalam konteks implementasi program CSR yang dikaitkan dengan modal sosial, kesejahteraan masyarakat dan reputasi perusahaan diantaranya bagi aspek managerial bahwa program CSR harus dapat meningkatkan kemampuan masyarakat untuk kegiatan yang berjangka panjang (berkelanjutan) bukan dalam konteks menghabiskan dana program, perusahaan harus terus mendorong masyarakat penerima program memiliki tanggungjawab dan rasa memiliki atas program yang diimplementasikan dalam rangka memperkuat modal sosialnya. 
Implikasi terakhir adalah perusahaan harus mengimplementasikan program CSR yang lebih konkret dalam peningkatan pendapatan secara ekonomi karena menjadi tujuan utama dalam konsep triple bottom CSR.

\section{PUSTAKA ACUAN}

Ana Jacinto, Isabel Carvalho. (2009). "Corporate Social Responsibility: The Influence of Organizational Practices Perceptions in Employee's Performance and Organizational Identification." Criteos: 205-26.

Ansari, Shahzad, Kamal Munir, and Tricia Gregg. (2012). "Impact at the 'Bottom of the Pyramid': The Role of Social Capital in Capability Development and Community Empowerment." Journal of Management Studies 49(4). 813-42.

Aprianthiny, Kadek. 2015. "Implementasi Corporate Social Responsibility (CSR) Sebagai Modal Sosial PT.Newmont." Jurusan Pendidikan Ekonomi (JJPE) 5(2). 1-12.

Arendt, Sebastian, and Malte Brettel. (2010). "Understanding the Influence of Corporate Social Responsibility on Corporate Identity, Image, and Firm Performance." Management Decision 48(10). 1469-92.

Ariefianto, L. (2015). "Program Corporate Social Responsibility (CSR) PT Semen Indonesia Tbk Dan Dampaknya Terhadap Keberdayaan Masyarakat." Pancaran Pendidikan 4(02). 20.

Astiti, Ni Putu Yeni, and Putu Wenny Saitri. (2016). "Pengaruh Corporate Social Responsibility Terhadap Kesejahteraan Masyarakat Dan Citra Perusahaan." Jurnal Bisnis Dan Kewirausahaan 12(2). 114-25.

Cahyono, Budhi. (2014). "Peran Modal Sosial Dalam Peningkatan Kesejahteraan Masyarakat Petani Tembakau Di Kabupaten Wonosobo." Jurnal EKOBIS 15(1). 1-16.

Carroll, Archie B., and Kareem M. Shabana. (2010). "The Business Case for Corporate Social Responsibility: A Review of Concepts, Research and Practice." International Journal of Management Reviews 12(1). 85-105.

Chintia, Chintia, and Fredian Tonny Nasdian. (2017). "Modal Sosial Dan Keberlanjutan Kelembagaan Dalam Program CSR PT Tirta Investama Di Kabupaten Cianjur Jawa Barat." Jurnal Sains Komunikasi dan Pengembangan Masyarakat [JSKPM] 1(1). 17.

Giannarakis, Grigoris, George Konteos, Eleni Zafeiriou, and Xanthi Partalidou. (2016). "The Impact of Corporate Social Responsibility on Financial Performance." Investment Management and Financial Innovations 13(3). 171-82.

Hadi, Nor. (2011). Corporate Social Responsibility (CSR). Edisi 1. Jakarta: Graha Ilmu.

Hasan Asy’ari. (2009). Universitas Diponegoro “Implementasi Corporate Social Responsibility (CSR) Sebagai Modal Sosial Pada PT Newmont." Universitas Diponegoro. eprints.undip. ac.id/17529/\%0A.php/rev_venes/article/view/1112.

Hoi, Chun Keung, Qiang Wu, and Hao Zhang. (2018). "Community Social Capital and Corporate Social Responsibility." Journal of Business Ethics 152(3). 647-65.

Ismail, Maimunah, Siti Noormi Alias, and Roziah Mohd Rasdi. (2015). "Community as 
Stakeholder of the Corporate Social Responsibility Programme in Malaysia: Outcomes in Community Development." Social Responsibility Journal 11(1). 109-30.

Jamali, Dima, and Charlotte Karam. (2018). "Corporate Social Responsibility in Developing Countries as an Emerging Field of Study." International Journal of Management Reviews 20(1). 32-61.

Lins, Karl V., Henri Servaes, and Ane Tamayo. (2017). "Social Capital, Trust, and Firm Performance: The Value of Corporate Social Responsibility during the Financial Crisis." Journal of Finance 72(4). 1785-1824.

Mapisangka, Andi. (2009). "Implementasi CSR Terhadap Kesejahteraan Hidup Masyarakat." Jurnal Ekonomi dan Studi Pembangunan 1(1).

Maroni, Ardy, Aji Ratna Kusuma, and Anwar Alaydrus. (2017). "Pengaruh Program Corporate Social Responsibility (Csr) Pt. Rea Kaltim Terhadap Kesejahteraan Masyarakat Desa Pulau Pinang Kecamatan Kembang Janggut Kabupaten Kutai Kartanegara." eJournal Ilmu Pemerintahan 6(2). 645-56.

Mentari, Rury Atmi. (2013). "Implementasi Corporate Social Responsibility (CSR) Pada Pendidikan." Jurnal Akuntansi Unesa 2(1). 1-24.

Moch, Saleh, and Sukaris. (2018). Corporate Social Responsibility Best Practice PT PJB UP Gresik. satu tahun. Gresik: UMG Press. http://eprints.umg.ac.id/1005/1/sertifikat_ EC00201814432.pdf.

Narsa, I Made, and Andry Irwanto. (2014). "Implementasi Tanggung Jawab Sosial PT Petrokimia Gresik Pada Masyarakat Lokal: Apa Kata Mereka?" Jurnal Akuntansi Multiparadigma 5(3). 450-65.

Nirmaya, Gilar Cahya, Istiqlaliyah Muflikhati, and Megawati Simanjuntak. (2014). "Pengaruh Program Corporate Social Responsibility (CSR) Terhadap Kesejahteraan Keluarga Di Sekitar Tambang." Jur. Ilm. Kel. \& Kons 7(1). 19-29.

Nugraha, Aat Ruchiat, Suwandi Sumartias, Evi Novianti, and Kokom Komariah. (2015). "Implementasi Kegiatan Corporate Social Responsibility 'Go Green Economic' Berbasiskan Kearifan Lokal." Jurnal Komunikasi 7(2). 118-28.

Peloza, John, and Loren Falkenberg. (2012). "The Role of Collaboration in Achieving Corporate Social Responsibility Objectives." California Management Review 51(3). 95-113.

Permanasari, Wien Ika. (2010). "Pengaruh Kepemilikan Manajemen, Kepemilikan Institusional Dan Corporate Social Responsibility Terhadap Nilai Perusahaan." Jurnal Akuntansi: 209-38.

Putu Wenny Saitri, I Ketut Sunarwijaya. (2016). "Pengaruh Corporate Social Responsibility Berbasis Tri Hita Karana Terhadap Kesejahteraan Masyarakat (Studi Empiris Pada Masyarakat Desa Sanur)." 266-72.

Rahmadani, Rahmadani, Santoso Tri Raharjo, and Risna Resnawaty. (2019). "Fungsi Corporate Social Responsibility (CSR) Dalam Pengembangan Dan Pemberdayaan Masyarakat." Share: Social Work Journal 8(2). 203.

Rosyida, Isma, and Fredian Tonny Nasdian. (2011). "Partisipasi Masyarakat Dan Stakeholder 
Dalam Penyelenggaraan Program Corporate Social Responsibility (CSR) Dan Dampaknya Terhadap Komunitas Perdesaan." Jural Transdisiplin Sosiologi, Komunikasi, dan Ekologi Manusia 05(01). 51-70.

Sa'Diyah, Tria Halimatu, and Sri Rahayu Budiani. (2015). "Hubungan Keberhasilan Program Corporate Social Responsibility (CSR) Dengan Kesejahteraan Masyarakat." Jurnal Bumilndonesia 4(4). 1-10.

Semuel, Hatane, and Elianto Wijaya. (2007). "Corporate Social Responsibility, Purchase Intention Dan Corporate Image Pada Restoran Di Surabaya Dari Perspektif Pelanggan." Jurnal Manajemen Pemasaran 3(1). 35-54.

Septiana, Rika Amelia. (2012). "Pengaruh Implementasi Corporate Social Responsibility Terhadap Profitabilitas Perusahaan.” Jurnal Pendidikan Ekonomi \& Bisnis 4(2). 71-84. Setyaningrum, Dyah Ayu. (2011). "Pengaruh Implementasi Corporate Social Responsibility Terhadap Kesejahteraan Hidup Masyarakat ( Studi Kasus Pada PT . Apac Inti Corpora , Bawen ).” Universitas Diponegoro Semarang. http://eprints.undip.ac.id/33083/1/ Skripsi_13.pdf.

Simorangkir OP. (2003). Etika Bisnis, Jabatan, Dan Perbankan. VIi. Jakarta: Rineka Cipta,. Sofyanty, Yossie Ria, Djamhur Hamid, and Rizki Yudhi Dewantara. (2017). “Analisis Penerapan CSR Dan Dampaknya Terhadap Kehidupan Sosial Ekonomi Masyarakat (Studi Kasus Pada Hotel Ibis Surabaya City Center)." Jurnal Administrasi Bisnis 42(2). 26-31.

Supono, Boedyo. (2011). "Peranan Modal Sosial Dalam Implementasi Manajemen Dan Bisnis." Jurnal Ekonomi dan Kewirausahaan 11(1). 10-16.

Suryani, Rezky Aditya, and Yan Hendra. (2018). "Implementasi Corporate Social Responsibility Pt. Pertamina (Persero) Refinery Unit Ii Dumai Untuk Peningkatan Taraf Hidup Masyarakat." Jurnal Interaksi 2(1). 85-106.

Susanti, Rina, and Titik Mildawati. (2014). "Pengaruh Kepemilikan Manajemen, Kepemilikan Institusional, Dan Corporate Social Responsibility Terhadap Nilai Perusahaan.” Jurnal Ilmu \& Riset Akuntansi 3(1). 1-86.

Syahra, Rusydi. (2003). “Modal Sosial: Konsep Dan Aplikasi.” Jurnal Masyarakat dan Budaya 5(1). 1-22.

Wang, Heli, Li Tong, Riki Takeuchi, and Gerard George. (2016). "Corporate Social Responsibility: An Overview and New Research Directions." Academy of Management Journal 59(2). 534-44.

Wibisono, Yusuf. (2007). "Membedah Konsep \& Aplikasi CSR: Corporate Social Responsibility." 163.

Young, Suzanne, and Vijaya Thyil. (2014). "Corporate Social Responsibility and Corporate Governance: Role of Context in International Settings.” Journal of Business Ethics 122(1). 1-24. 